\title{
Characterization and productivity profiles of Aedes aegypti (L.) breeding habitats across rural and urban landscapes in western and coastal Kenya
}

Harun N. Ngugi ${ }^{1,5^{*}}$, Francis M. Mutuku ${ }^{2}$, Bryson A. Ndenga ${ }^{3}$, Peter S. Musunzaji ${ }^{4}$, Joel O. Mbakaya ${ }^{3}$, Peter Aswani ${ }^{3}$, Lucy W. Irungu ${ }^{5}$, Dunstan Mukoko ${ }^{6}$, John Vulule ${ }^{3}$, Uriel Kitron ${ }^{7}$ and Angelle D. LaBeaud ${ }^{8}$

\begin{abstract}
Background: Aedes aegypti, the principal vector for dengue and other emerging arboviruses, breeds preferentially in various man-made and natural container habitats. In the absence of vaccine, epidemiological surveillance and vector control remain the best practices for preventing dengue outbreaks. Effective vector control depends on a good understanding of larval and adult vector ecology of which little is known in Kenya. In the current study, we sought to characterize breeding habitats and establish container productivity profiles of Ae. aegypti in rural and urban sites in western and coastal Kenya.
\end{abstract}

Methods: Twenty sentinel houses in each of four study sites (in western and coastal Kenya) were assessed for immature mosquito infestation once a month for a period of 24 months (June 2014 to May 2016). All water-holding containers in and around the households were inspected for Ae. aegypti larvae and pupae.

Results: Collections were made from a total of 22,144 container visits: Chulaimbo (7575) and Kisumu (8003) in the west, and from Msambweni (3199) and Ukunda (3367) on the coast. Of these, only 4-5.6\% were positive for Ae. aegypti immatures. In all four sites, significantly more positive containers were located outdoors than indoors. A total of 17,537 Ae. aegypti immatures were sampled from 10 container types. The most important habitat types were buckets, drums, tires, and pots, which produced over $75 \%$ of all the pupae. Key outdoor containers in the coast were buckets, drums and tires, which accounted for $82 \%$ of the pupae, while pots and tires were the only key containers in the western region producing $70 \%$ of the pupae. Drums, buckets and pots were the key indoor containers, producing nearly all of the pupae in the coastal sites. No pupae were collected indoors in the western region. The coastal region produced significantly more Ae. aegypti immatures than the western region both inside and outside the sentinel houses.

Conclusions: These results indicate that productive Ae. aegypti larval habitats are abundant outdoors and that only a few containers produce a majority of the pupae. Although the numbers were lower, productive habitats were detected within households. Targeting source reduction efforts towards these productive containers both inside and outside homes is likely to be a cost-effective way to reduce arboviral transmission in these regions.

Keywords: Aedes aegypti, Larval habitats, Productivity, Western and coastal Kenya, Household breeding surveys

\footnotetext{
* Correspondence: ngugihn09@gmail.com

${ }^{1}$ Department of Biological Sciences, Chuka University, Chuka, Kenya

${ }^{5}$ Department of Zoology, School of Biological Sciences University of Nairobi,

Nairobi, Kenya

Full list of author information is available at the end of the article
} 


\section{Background}

Aedes aegypti, the principal vector for dengue, chikungunya, and other emerging arboviruses, is closely associated with human dwellings in endemic areas, and breeds preferentially in natural and man-made container habitats of various characteristics [1-5]. In Kenya, the first dengue outbreak was reported in 1982 [6], with more recent outbreaks reported in Mombasa [7] and the northeastern town of Mandera [8]. These recent dengue outbreaks involved three different dengue virus (DENV) serotypes (DENV-1, DENV-2 and DENV-3) [7, 8]. In Kenya, dengue appears to be endemic with periodic outbreaks primarily occurring along the coast in recent years [7-9]. Earlier studies reported seroprevalence of $1.1 \%$ to $7.5 \%$ in western Kenya outside the known epidemic periods [10, 11]. Similar studies in coastal Kenya revealed DENV seroprevalence ranging from $1 \%$ to $53 \%[11,12]$.

In Kenya, the two subspecific taxa, Ae. aegypti aegypti and Ae. aegypti formosus are the primary dengue vectors [13] with the latter being more prevalent in western Kenya [14]. Aedes ae. aegypti is more common in human dwellings, while Ae. ae. formosus, the sylvatic form, breeds in forest treeholes [13, 15]. The two subspecies were found to occur sympatrically along the coast of Kenya [13]. Larvae of Ae. aegypti and Culex spp. are often reported co-occurring in the same breeding sites [16-18]. In the coastal town of Malindi, Ae aegypti immatures were found both indoors and outdoors at high numbers [19]. In a recent study [20], Ae. aegypti was reported to breed mostly outdoors, in what may be a novel adaptive strategy by this vector, which traditionally is considered to have adapted to the domestic environment and breed mainly in indoor water storage containers [13, 21, 22]. Predominantly outdoor breeding by Ae. aegypti has also been observed in the city of Mombasa, where recent outbreaks of dengue have been reported [23]. The outdoor environment offers more breeding opportunities due to the availability of numerous rain-filled discarded containers. Heterogeneous populations of Ae. aegypti were found to occur in such habitats for relatively long periods of time [20]. Human activities involving water storage, use and disposal of water-holding containers greatly influence Ae.aegypti breeding in individual households. Some of the key factors that may influence productivity of Ae.aegypti in different container types include, the frequency of water replenishment, the availability of food for the larvae [24], the degree of sunlight exposure [25] and container covering [26].

There are few studies on the larval habitat productivity of Ae. aegypti in Kenya [13, 14, 19], despite the evidence of dengue and chikungunya virus transmission in Kenya in recent years $[7-9,27,28]$. The presence of DENV and other arboviruses in Kenya [29], coupled with ideal ecological conditions for the vector mosquitoes, increases the risk for DENV outbreaks in this region. In the absence of a vaccine, epidemiological surveillance and vector control remain the best practices for preventing dengue outbreaks [22, 30-32]. Effective vector control depends on a good understanding of larval and adult vector ecology of which little is known in Kenya. The purpose of this study is to characterize breeding habitats and establish container productivity profiles of Ae.aegypti in rural and urban sites in western and coastal Kenya. By determining the container habitat characteristics that influence the selection of a breeding habitat by Ae.aegypti mosquitoes, key container habitats can be identified and targeted for effective larval source reduction efforts in dengue vector control programs.

\section{Methods}

\section{Study sites}

Mosquito surveys were conducted in the western and coastal regions of Kenya. In the coastal region two sites, each covering $25 \mathrm{~km}^{2}$, both in Kwale County, South Coast were studied: Ukunda, an urban site $\left(4^{\circ} 17^{\prime} 59.9994^{\prime \prime} \mathrm{S}, 39^{\circ}\right.$ 34'59.8794"'E), and Msambweni, a rural site ( $4^{\circ} 28^{\prime} 0.0114^{\prime \prime}$ $\left.\mathrm{S}, 39^{\circ} 28^{\prime} 0.12^{\prime \prime} \mathrm{E}\right)$, located approximately 30 and $60 \mathrm{~km}$ south of the port city of Mombasa, respectively. The coastal climate is tropical: hot and humid throughout the year with annual mean temperatures of $23-34{ }^{\circ} \mathrm{C}$ and average relative humidity of $60-80 \%$. Ukunda is a rapidly growing urban center with population density of about 2000 people $/ \mathrm{km}^{2}$. The area is characterized by a proliferation of unplanned residential houses, with unreliable water, sewer and waste management systems. Most residents engage in small-scale trade, fishing and casual labour in the tourist industry along the Indian Ocean coast. Msambweni is a rural area with a population density of about 460 people $/ \mathrm{km}^{2}$, where most of the residents are fishermen and subsistence farmers. Residents rely mainly on wells and rainfall for their water for domestic use, since the piped water system is inadequate and unreliable.

In the west, two sites, each covering approximately $25 \mathrm{~km}^{2}$, both in Kisumu County were studied: Kisumu, an urban site located on the shore of Lake Victoria $\left(0.1000^{\circ} \mathrm{S}, 34.7500^{\circ} \mathrm{E}\right.$ elevation $\left.1100 \mathrm{~m}\right)$, and Chulaimbo, a rural site $19 \mathrm{~km}$ west of Kisumu City $\left(0.03572^{\circ} \mathrm{S}\right.$, $34.621^{\circ} \mathrm{E}$, elevation $1328 \mathrm{~m}$ ). The region has a mean annual temperature range of $12-35{ }^{\circ} \mathrm{C}$, with an average annual rainfall of $1352 \mathrm{~mm}$ and average relative humidity range of $66-83 \%$. Kisumu site has a density of about 15,000 people/ $\mathrm{km}^{2}$, most of them in the low income bracket. About 75\% of the study site falls within an unplanned settlement area and $25 \%$ within a well-planned residential area. The site has intermittent water supply system, and limited sewer and waste disposal, especially in the unplanned area. Chulaimbo has a population density of about 500 people $/ \mathrm{km}^{2}$. Most residents are small-scale subsistence farmers. 
Residents in the four study sites store water for domestic use in diverse containers because the water supply system is unreliable. Water supply in the rural study sites is mainly from harvested rainwater, wells and boreholes, and these also supplement the irregular piped water supply system characteristic of our urban study sites. The study regions are characterized by four seasons: long dry (January-March), long rainy (April-June), short dry season (July-September), and short rainy (October-December) [33-35].

\section{Mosquito surveys}

Prior to the mosquito surveys, mapping and a demographic survey were conducted in all households in all study sites. Forty sentinel houses in each of the four study sites were then selected from the mapped houses by simple random sampling; 20 houses for larval sampling and the other 20 for ovitrap surveys. Practicability of repeated mosquito surveys in sentinel houses in each site over an extended period ( 2 years) guided the choice of 40 houses. During mosquito surveys the selected 20 sentinel houses were assessed for immature mosquito infestation once a month for a period of 24 months (June 2014 to May 2016). For the mosquito surveys, a household was defined as a single residential building, and its surrounding area within approximately a $10 \mathrm{~m}$ radius. The distance between selected households ranged from 100 to $200 \mathrm{~m}$. Informed consent was obtained from all heads of households, and when a house was inaccessible, it was replaced by the nearest house.

All natural and artificial water-holding containers in and around each household were inspected for mosquito larvae and pupae. All pupae and larvae (3rd and 4th instars) from positive containers were collected with the aid of pipettes and ladles [36], counted and recorded on field-data forms. Water from large containers was first sieved and mosquito samples were placed in a white plastic tray with some water from which the immatures were pipetted. Mosquito samples were placed in $10 \mathrm{ml}$ falcon tubes and/or Whirl-pak ${ }^{\oplus}$ plastic bags (Nasco, Fort Atkinson, WI), labeled, and taken to the Vector Borne Disease Control Unit (VBDCU) laboratory in Msambweni Hospital for the coastal sites or the Kenya Medical Research Institute (KEMRI) Laboratory in Kisumu for the western study sites. Immature mosquitoes were reared in $200 \mathrm{ml}$ plastic cups under laboratory conditions at an average temperature of $28.15 \pm 1.8^{\circ} \mathrm{C}$ and relative humidity of $80.9 \pm 6.3 \%$, and larvae were fed on TetraMinbaby ${ }^{\circ}$ fish food (Tetra Werke, Melle, Germany). Emerged adults were identified to species using standard taxonomic keys [37]. We distinguished Ae. aegypti (L.) subspecies morphologically following keys as provided by Edwards [37], Mattingly [38] and Huang [39].

\section{Ovitrap survey}

Two modified ovitraps were placed in 20 households that were randomly selected as fixed sampling points in each of our four study sites. Each ovitrap consisted of a black plastic cup and filled with about $350 \mathrm{ml}$ of tap, borehole or rainwater. The inside of the cup was lined by a brown paper towel that was partially submerged. Eggs were laid on the damp paper towel just above the water line. The indoor trap was placed on ground level in a dark sheltered location of the living or bed room. Outdoor ovitraps were placed within a $10 \mathrm{~m}$ radius in suitably sheltered locations. Ovitraps were set once a week every month for a period of 24 months (June 2014 to May 2016). The ovitraps were serviced [40] after 5 days. First the paper towel in each trap was removed, wrapped in white tissue paper and placed in a plastic Ziploc bag that was labeled with house number and location of the trap. Each paper towel was examined under the dissecting microscope $(\times 40)$ (Nikon', SMZ Japan) for identification and counting of Ae. aegypti eggs. To confirm the species, the eggs were submerged in seasoned tap water for hatching and larvae reared to adults which were identified using a standard taxonomic key [37].

\section{Classification and characterization of containers}

A total of ten container types were identified and classified based on their use and material: drums, animal feeding containers (AFC), tires, pots, small domestic containers (SDC), treeholes, wells, buckets, jerrycans and others. Drums were defined as 100-500 l capacity plastic or metal water storage containers. Animal feeding containers, ranged from small 11 bird watering and feeding containers made of plastic or cut tires, to large $300 \mathrm{l}$ concrete cattle watering containers. Pots included flower vases and water storage vessels made of clay. Small domestic containers included small plastic food containers, tins, bottles, plates, cans, cooking pots (sufuria) and jars. Others included; polythene bags, fallen leaves, coconut shells, hoof prints, drains, gutters, septic tanks, shoes, cisterns and sinks. Wells were open dugout pits used for water provision in homesteads. For each breeding habitat, records were made on the container type (small domestic container, bucket, jerrycan, tire, drums, animal feeding trough, pot, tree hole, well and other) and location in the household (indoor or outdoor).

\section{Weather data}

Daily temperature and relative humidity data was collected using $\mathrm{HOBO}$ data loggers (HOBO, Onset Computer Corporation, Bourne, MA, USA). Rainfall data were collected daily using event data logger rain gauges (HOBO, Onset Computer Corporation, Bourne, MA, USA) that were placed in each of the four study sites. 


\section{Data analysis}

Positive containers were those with one or more Ae. aegypti larvae or pupae. Proportion of wet containers that were positive in each site was determined and a Chi- square test was used to compare the distribution of positive containers between indoor and outdoor locations. Key larval habitats were defined as containers that are most productive for Ae aegypti pupae. KruskalWallis test was used to compare the distribution of Ae. aegypti infestation in the four study sites, and productivity between seasons. Mosquito indices were calculated as follows: container index (the percentage of containers infested with Ae. aegypti immatures) and pupae per person index (the number of pupae over the total number of persons in a household). Data analysis was performed using SAS 9.1 statistical software (SAS Institute, Gary, NC).

\section{Results}

\section{Seasonality and climate factors at four study sites}

During the study period, a mean annual temperature of $23-33^{\circ} \mathrm{C}$ and annual rainfall of $1244 \mathrm{~mm}$ were recorded for the coast region (Fig. 1). Seasonal variations in rainfall and temperature recorded for the two coastal study sites were similar (Ukunda: mean annual temperature of 23-34 ${ }^{\circ} \mathrm{C}$; average annual rainfall of $1188 \mathrm{~mm} /$ year and Msambweni: mean annual temperature $23-32{ }^{\circ} \mathrm{C}$ and average rainfall, $1300 \mathrm{~mm} /$ year). In the western region annual temperature range was $19-33{ }^{\circ} \mathrm{C}$ and average annual rainfall of $1335 \mathrm{~mm}$ (Fig. 2) (Kisumu: mean annual temperature $20-33{ }^{\circ} \mathrm{C}$ and rainfall $1130 \mathrm{~mm} /$ year and Chulaimbo: mean annual temperature $18-32{ }^{\circ} \mathrm{C}$ and rainfall $1538 \mathrm{~mm} /$ year).
Frequency and presence of Ae. aegypti immatures in containers

Collections were made from 22,144 wet container visits: Chulaimbo (7575), Kisumu (8003), Msambweni (3199) and Ukunda (3367). During the visits, some of the containers were repeatedly sampled. Of these, only 5.49, 4.60, 5.56 and 4.54\%, respectively, were positive for Ae. aegypti immatures. In all four sites, more positive containers were located outdoors $(94.8 \%)$ than indoors (5.2\%) $\left(\chi^{2}=895.1, d f=1, P<0.0001\right.$; Tables 1,2$)$. There was a significant variation in the proportion of $A e$. aegypti positive containers in outdoor locations among the four sites $\left(\chi^{2}=8.98, d f=3, P<0.05\right.$ (Chulaimbo: 38.5\%; Kisumu: 33.9\%; Msambweni: $15.5 \%$; and Ukunda: 12.1\%). Despite the low presence of Ae. aegypti-positive containers indoors, the proportion of wet containers indoors was higher (52.8\%) than that outdoors $(47.2 \%)$ in all the study sites $\left(\chi^{2}=67.7, d f=1, P<0.0001\right)$. However, for the indoor container habitats, a much higher proportion of Ae. aegypti-positive containers was observed in the coastal site of Ukunda (43.1\%) than in the other sites (Chulaimbo 12.1\%, Kisumu, 13.8\%, Msambweni 31\%) $\left(\chi^{2}=3, P<0.0001 ;\right.$ Table 2$)$.

\section{Container productivity}

A total of 26,197 immatures were collected from the four study sites. Of these, $67.3 \%$ were identified as Ae. aegypti. We identified all the Ae. aegypti in this study as Ae. aegypti aegypti and none as Aedes aegypti formosus. Other mosquito species included: Culex spp. (30.2\%), Ae. simpsoni (1.1\%), An. gambiae (0.2\%) and Toxorhynchites (1.1\%). A total of 17,635 immature Ae. aegypti were collected from 1115 positive container visits in western and coastal regions. Buckets, drums, tires, and

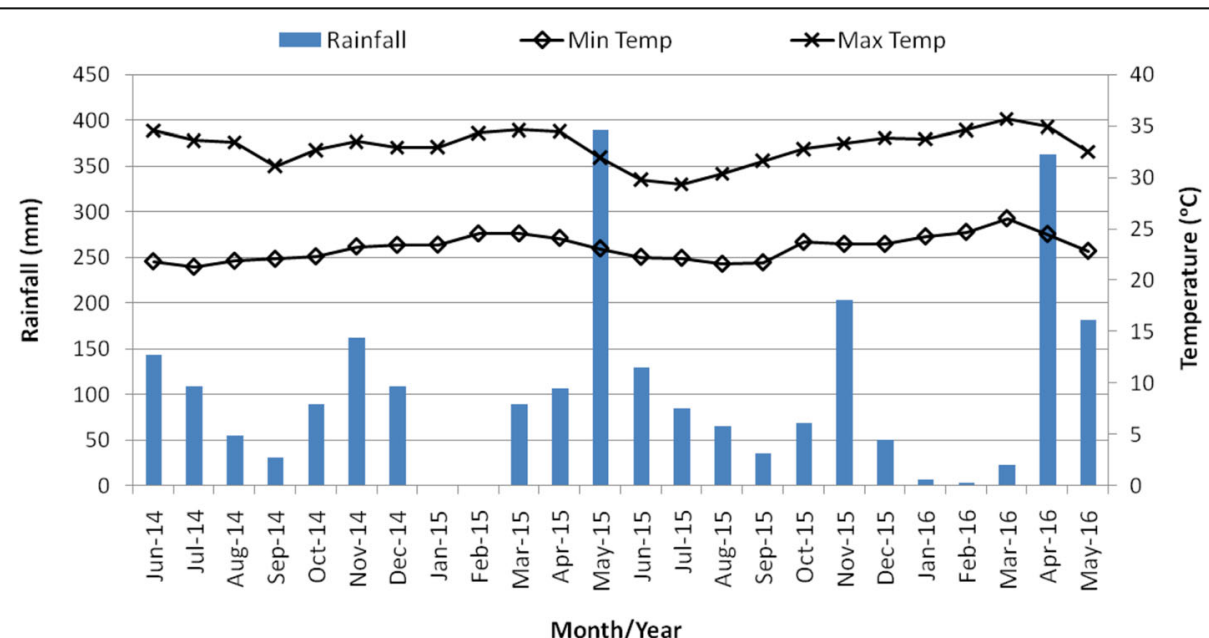

Fig. 1 Monthly distribution of rainfall, minimum and maximum temperatures for coastal region sites from June 2014 to May 2016. Seasons: long rainy (April-June), short dry (July-September), short rainy (October-December); long dry (January-March) 


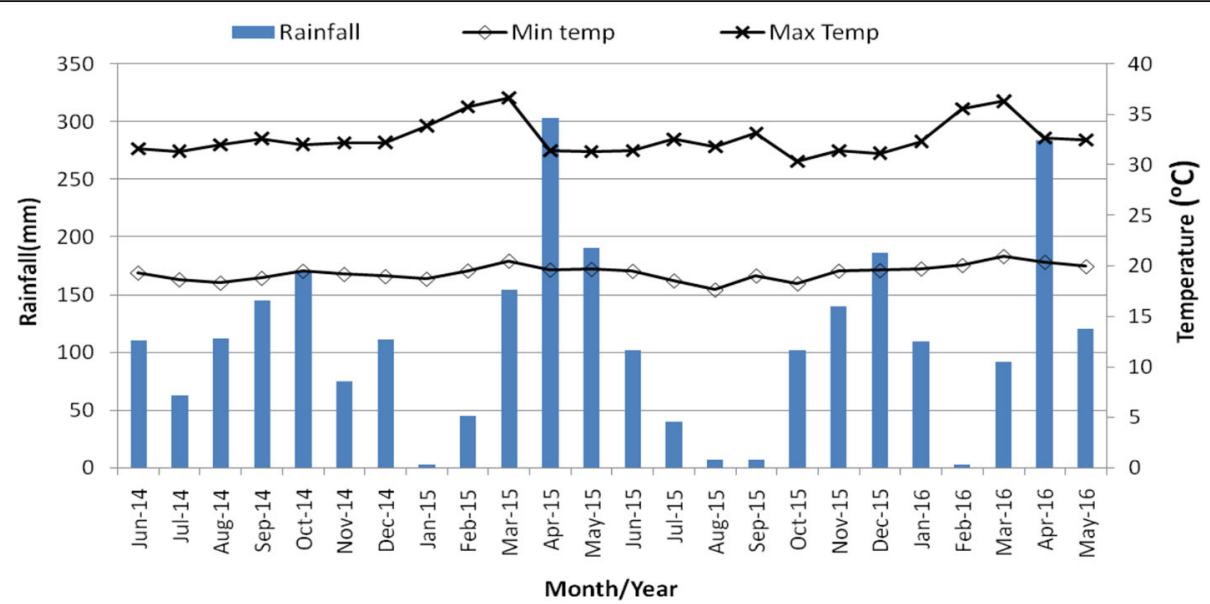

Fig. 2 Monthly distribution of rainfall, minimum and maximum temperatures for western region sites from June 2014 to May 2016. Seasons: long rainy (April-June), short dry (July-September), short rainy (October-December); long dry (January-March)

pots produced $77.4 \%(2704 / 3493)$ of Ae.aegypti pupae in the western and coastal study sites combined (Tables 1 , 2). Drums, buckets, and pots, were the key Ae. aegypti containers indoors, producing nearly all (190/193) collected Ae. aegypti pupae (Table 2). Important outdoor containers in the coastal region were buckets, drums, and tires. While in the western region, pots and tires were the main producers (Table 1).

When productivity among regions was compared, the coastal region produced significantly more Ae. aegypti immatures (Kruskal-Wallis test, $\chi^{2}=77.3, d f=1$, $P<0.0001)$ than the western region. In addition, productivity varied significantly between sites $\left(\chi^{2}=77.3, d f=3\right.$,
$P<0.0001)$. Over $70 \%$ of the containers inspected in both western and coast regions were for water storage (drums, pots, buckets and jerrycans) (Table 3). They contributed 63.1 and $75.2 \%$ of larvae and pupae, respectively, in the coastal region, while in the western region they contributed 60.1 and $55.0 \%$ of larvae and pupae, respectively. Other container types, such as tires, small domestic containers, animal food troughs, tree holes, and wells produced the rest of the larvae and pupae collected. Of these, tires contributed most of the larvae and pupae. Water storage containers are important producers especially indoors where they contributed nearly all the larvae and pupae (Table 2). Analysis of relative pupal productivity by

Table 1 Containers with larvae and pupae for outdoor locations for western [Chulaimbo: Rural (R) and Kisumu: Urban (U)] sites and coastal [Msambweni (R) and Ukunda (U)] sites, Kenya

\begin{tabular}{|c|c|c|c|c|c|c|c|c|c|c|c|c|c|c|c|}
\hline \multirow{3}{*}{$\begin{array}{l}\text { Container } \\
\text { type }\end{array}$} & \multicolumn{6}{|l|}{ Western } & \multicolumn{6}{|l|}{ Coastal } & \multirow{3}{*}{$\begin{array}{l}\text { Total no. of } \\
\text { container } \\
\text { visits (+ve) }\end{array}$} & \multirow{2}{*}{\multicolumn{2}{|c|}{$\begin{array}{l}\text { Total no. of } \\
\text { larvae and } \\
\text { pupae }\end{array}$}} \\
\hline & \multicolumn{3}{|c|}{ Chulaimbo (R) } & \multicolumn{3}{|l|}{ Kisumu (U) } & \multicolumn{3}{|c|}{ Msambweni (R) } & \multicolumn{3}{|c|}{ Ukunda (U) } & & & \\
\hline & $\begin{array}{l}\text { No. of } \\
\text { container } \\
\text { visits } \\
\text { (+ve) }\end{array}$ & $\begin{array}{l}\text { No. of } \\
\text { larvae }\end{array}$ & $\begin{array}{l}\text { No. of } \\
\text { pupae }\end{array}$ & $\begin{array}{l}\text { No. of } \\
\text { container } \\
\text { visits } \\
(+v e)\end{array}$ & $\begin{array}{l}\text { No. of } \\
\text { larvae }\end{array}$ & $\begin{array}{l}\text { No. of } \\
\text { pupae }\end{array}$ & $\begin{array}{l}\text { No. of } \\
\text { container } \\
\text { visits } \\
(+v e)\end{array}$ & $\begin{array}{l}\text { No. of } \\
\text { larvae }\end{array}$ & $\begin{array}{l}\text { No. of } \\
\text { pupae }\end{array}$ & $\begin{array}{l}\text { No. of } \\
\text { container } \\
\text { visits } \\
\text { (+ve) }\end{array}$ & $\begin{array}{l}\text { No. of } \\
\text { larvae }\end{array}$ & $\begin{array}{l}\text { No. of } \\
\text { pupae }\end{array}$ & & Larvae & Pupae \\
\hline Jerrycan & $458(5)$ & 19 & 4 & $290(5)$ & 11 & 2 & $164(10)$ & 155 & 16 & $368(9)$ & 100 & 18 & $1280(29)$ & 285 & 40 \\
\hline Bucket & $738(2)$ & 20 & 9 & $727(5)$ & 26 & 4 & $766(80)$ & 1523 & 468 & 559 (19) & 545 & 486 & 2790 (106) & 2114 & 967 \\
\hline Pot & 867 (346) & 1605 & 301 & $527(71)$ & 171 & 39 & $20(5)$ & 236 & 32 & $21(8)$ & 482 & 33 & 1435 (430) & 2494 & 405 \\
\hline Drum & 99 (3) & 25 & 5 & $270(51)$ & 263 & 48 & $113(38)$ & 2398 & 714 & $137(35)$ & 728 & 104 & 619 (122) & 3414 & 871 \\
\hline SDC & $742(20)$ & 151 & 22 & $681(88)$ & 284 & 39 & $145(18)$ & 547 & 134 & $178(7)$ & 191 & 36 & $1746(133)$ & 1173 & 231 \\
\hline AFC & $66(6)$ & 50 & 19 & 79 (10) & 21 & 8 & $33(3)$ & 12 & 5 & $53(11)$ & 891 & 99 & $231(30)$ & 974 & 131 \\
\hline Tire & $33(5)$ & 40 & 3 & $243(120)$ & 607 & 182 & $18(6)$ & 541 & 127 & $64(28)$ & 1365 & 206 & 358 (159) & 2553 & 518 \\
\hline Tree hole & $32(17)$ & 153 & 49 & $4(4)$ & 35 & 8 & 0 & 0 & 0 & 0 & 0 & 0 & $36(21)$ & 188 & 57 \\
\hline Well & $28(5)$ & 48 & 5 & $33(0)$ & 0 & 0 & 0 & 0 & 0 & 0 & 0 & 0 & $61(5)$ & 48 & 5 \\
\hline Other & $960(0)$ & 0 & 0 & 747 (6) & 39 & 2 & $81(5)$ & 163 & 24 & $116(11)$ & 175 & 49 & 1904 (22) & 377 & 75 \\
\hline
\end{tabular}


Table 2 Container types with larvae and pupae for indoor locations in western [Chulaimbo: Rural (R) and Kisumu: Urban (U)] sites and coastal [Msambweni (R) and Ukunda (U)] sites, Kenya

\begin{tabular}{|c|c|c|c|c|c|c|c|c|c|c|c|c|c|c|c|}
\hline \multirow{3}{*}{$\begin{array}{l}\text { Container } \\
\text { type }\end{array}$} & \multicolumn{6}{|l|}{ Western } & \multicolumn{6}{|l|}{ Coastal } & \multirow{3}{*}{$\begin{array}{l}\text { Total no. of } \\
\text { container } \\
\text { visits (+ve) }\end{array}$} & \multirow{2}{*}{\multicolumn{2}{|c|}{$\begin{array}{l}\text { Total no. of } \\
\text { larvae and } \\
\text { pupae }\end{array}$}} \\
\hline & \multicolumn{3}{|c|}{ Chulaimbo (R) } & \multicolumn{3}{|l|}{ Kisumu (U) } & \multicolumn{3}{|c|}{ Msambweni (R) } & \multicolumn{3}{|c|}{ Ukunda (U) } & & & \\
\hline & $\begin{array}{l}\text { No. of } \\
\text { container } \\
\text { visits } \\
(+\mathrm{ve})\end{array}$ & $\begin{array}{l}\text { No. of } \\
\text { larvae }\end{array}$ & $\begin{array}{l}\text { No. of } \\
\text { pupae }\end{array}$ & $\begin{array}{l}\text { No. of } \\
\text { container } \\
\text { visits } \\
(+\mathrm{ve})\end{array}$ & $\begin{array}{l}\text { No. of } \\
\text { larvae }\end{array}$ & $\begin{array}{l}\text { No. of } \\
\text { pupae }\end{array}$ & $\begin{array}{l}\text { No. of } \\
\text { container } \\
\text { visits } \\
\text { (+ve) }\end{array}$ & $\begin{array}{l}\text { No. of } \\
\text { larvae }\end{array}$ & $\begin{array}{l}\text { No. of } \\
\text { pupae }\end{array}$ & $\begin{array}{l}\text { No. of } \\
\text { container } \\
\text { visits } \\
(+v e)\end{array}$ & $\begin{array}{l}\text { No. of } \\
\text { larvae }\end{array}$ & $\begin{array}{l}\text { No. of } \\
\text { pupae }\end{array}$ & & Larvae & Pupae \\
\hline Jerrycan & $1729(4)$ & 3 & 0 & $2111(6)$ & 2 & 0 & $400(1)$ & 0 & 1 & $785(5)$ & 18 & 1 & $5025(16)$ & 23 & 2 \\
\hline Bucket & $836(0)$ & 0 & 0 & $1108(2)$ & 2 & 0 & 1159 (9) & 73 & 26 & $666(5)$ & 19 & 0 & 3769 (16) & 94 & 26 \\
\hline Pot & $317(0)$ & 0 & 0 & $204(0)$ & 0 & 0 & $58(0)$ & 0 & 0 & $27(2)$ & 45 & 45 & $606(2)$ & 45 & 45 \\
\hline Drum & $186(2)$ & 5 & 0 & $246(0)$ & 0 & 0 & $201(7)$ & 195 & 91 & $294(12)$ & 147 & 28 & $927(21)$ & 347 & 119 \\
\hline SDC & $124(0)$ & 0 & 0 & $105(0)$ & 0 & 0 & $15(1)$ & 0 & 1 & $85(1)$ & 11 & 0 & $329(2)$ & 11 & 1 \\
\hline AFC & 0 & 0 & 0 & 0 & 0 & 0 & 0 & 0 & 0 & 2 & 0 & 0 & $2(0)$ & 0 & 0 \\
\hline Tire & 0 & 0 & 0 & 0 & 0 & 0 & 0 & 0 & 0 & 0 & 0 & 0 & 0 & 0 & 0 \\
\hline Tree hole & 0 & 0 & 0 & 0 & 0 & 0 & 0 & 0 & 0 & 0 & 0 & 0 & 0 & 0 & 0 \\
\hline Well & 0 & 0 & 0 & 0 & 0 & 0 & 0 & 0 & 0 & 0 & 0 & 0 & 0 & 0 & 0 \\
\hline Other & $360(1)$ & 2 & 0 & $628(0)$ & 0 & 0 & $26(0)$ & 0 & 0 & $12(0)$ & 0 & 0 & $1026(1)$ & 2 & 0 \\
\hline
\end{tabular}

Abbreviations: AFC animal feeding containers, SDC small domestic containers, +ve positive

different container categories showed that buckets, drums and tires were the most productive in the coastal region overall with $35.6,34.1$ and $12.1 \%$ pupae per container type, respectively (Table 4). While in the western region pots and tires were the two most productive container types with 45.4 and $24.7 \%$ pupae per container, respectively (Table 5). Pupal index was notably higher (0.92) in the rural site of western Kenya than in the other three study sites (Ukunda: 0.47; Kisumu: 0.35; and Msambweni: 0.35).

\section{Seasonal distribution of Ae. aegypti in wet containers}

The abundance and distribution of different types of containers followed a consistent pattern over the dry and rainy seasons in western and coast regions (Fig. 3). Immature $A e$. aegypti were found in more container

Table 3 Productivity of water storage containers in comparison to other container types in rural (R) and urban (U) sites of western and coastal regions, Kenya

\begin{tabular}{|c|c|c|c|c|c|c|c|c|c|c|c|c|}
\hline \multirow{3}{*}{$\begin{array}{l}\text { Container } \\
\text { type }\end{array}$} & \multicolumn{6}{|l|}{ Western region } & \multicolumn{6}{|l|}{ Coastal region } \\
\hline & \multicolumn{3}{|l|}{ Chulaimbo (R) } & \multicolumn{3}{|l|}{ Kisumu (U) } & \multicolumn{3}{|l|}{ Msambweni (R) } & \multicolumn{3}{|l|}{ Ukunda (U) } \\
\hline & $\begin{array}{l}\text { No. of container } \\
\text { visits (+ve) }\end{array}$ & $\begin{array}{l}\text { No. of } \\
\text { larvae }\end{array}$ & $\begin{array}{l}\text { No. of } \\
\text { pupae }\end{array}$ & $\begin{array}{l}\text { No. of container } \\
\text { visits (+ve) }\end{array}$ & $\begin{array}{l}\text { No. of } \\
\text { larvae }\end{array}$ & $\begin{array}{l}\text { No. of } \\
\text { pupae }\end{array}$ & $\begin{array}{l}\text { No. of container } \\
\text { visits (+ve) }\end{array}$ & $\begin{array}{l}\text { No. of } \\
\text { larvae }\end{array}$ & $\begin{array}{l}\text { No. of } \\
\text { pupae }\end{array}$ & $\begin{array}{l}\text { Container } \\
\text { visit (+ve) }\end{array}$ & $\begin{array}{l}\text { No. of } \\
\text { larvae }\end{array}$ & $\begin{array}{l}\text { No. of } \\
\text { pupae }\end{array}$ \\
\hline Jerrycan & $2187(9)$ & 22 & 4 & $240(11)$ & 13 & 2 & $5,46(11)$ & 155 & 17 & $1153(14)$ & 118 & 19 \\
\hline Bucket & $1574(2)$ & 20 & 9 & $1835(7)$ & 28 & 4 & $1925(89)$ & 1596 & 494 & $1225(24)$ & 564 & 486 \\
\hline Pot & $1184(346)$ & 1605 & 301 & $731(71)$ & 171 & 39 & $78(5)$ & 236 & 32 & $48(10)$ & 527 & 78 \\
\hline Drum & $285(5)$ & 30 & 5 & $516(51)$ & 263 & 48 & $314(40)$ & 2593 & 805 & $431(47)$ & 875 & 132 \\
\hline Total & $5230(362)$ & 1677 & 319 & $3322(140)$ & 475 & 93 & $2863(145)$ & 4580 & 1348 & $2857(95)$ & 2084 & 715 \\
\hline \multicolumn{13}{|c|}{ Other container types } \\
\hline SDC & $866(20)$ & 151 & 22 & $786(88)$ & 284 & 39 & $160(19)$ & 547 & 135 & $263(8)$ & 202 & 36 \\
\hline AFC & $66(6)$ & 50 & 19 & $79(10)$ & 21 & 8 & $33(3)$ & 12 & 5 & $55(11)$ & 891 & 99 \\
\hline Tire & $33(5)$ & 40 & 3 & $243(120)$ & 607 & 182 & $18(6)$ & 541 & 127 & $64(28)$ & 1365 & 206 \\
\hline Treehole & 32 (17) & 153 & 49 & $4(4)$ & 35 & 8 & 0 & 0 & 0 & 0 & 0 & 0 \\
\hline Well & $28(5)$ & 48 & 5 & $33(0)$ & 0 & 0 & 0 & 0 & O & 0 & 0 & 0 \\
\hline Other & $1320(1)$ & 2 & 0 & $1375(6)$ & 39 & 2 & 107 (5) & 163 & 24 & $128(11)$ & 175 & 49 \\
\hline Total & 2345 (54) & 444 & 98 & $2520(228)$ & 986 & 239 & $318(33)$ & 1263 & 291 & $510(58)$ & 2633 & 390 \\
\hline
\end{tabular}


Table 4 Relative importance of container categories in the coastal region, Kenya

\begin{tabular}{|c|c|c|c|c|c|c|c|c|}
\hline $\begin{array}{l}\text { Container } \\
\text { category }\end{array}$ & $\begin{array}{l}\text { No. of container } \\
\text { visits (+ve) }\end{array}$ & $\begin{array}{l}\text { Total no. of larvae } \\
\text { in each container } \\
\text { category }\end{array}$ & $\begin{array}{l}\text { Proportion of } \\
\text { larvae in each } \\
\text { container } \\
\text { category (\%) }\end{array}$ & $\begin{array}{l}\text { No. of } \\
\text { containers } \\
\text { with pupae }\end{array}$ & $\begin{array}{l}\text { Total no. of pupae } \\
\text { in each container } \\
\text { category }\end{array}$ & $\begin{array}{l}\text { No. of pupae per } \\
\text { container type } \\
\text { (Mean } \pm \text { SD) }\end{array}$ & $\begin{array}{l}\text { Frequency of } \\
\text { containers with } \\
\text { pupae (\%) }\end{array}$ & $\begin{array}{l}\text { Proportion of } \\
\text { pupae in each } \\
\text { container } \\
\text { category (\%) }\end{array}$ \\
\hline Bucket & $3150(113)$ & 2160 & 20.73 & 31 & 980 & $0.31 \pm 6.43$ & 0.98 & 35.64 \\
\hline Drum & 745 (87) & 3468 & 33.28 & 41 & 937 & $1.26 \pm 11.70$ & 1.30 & 34.07 \\
\hline Tires & $82(34)$ & 1906 & 18.29 & 19 & 333 & $4.06 \pm 11.51$ & 0.60 & 12.11 \\
\hline SDC & $423(27)$ & 749 & 7.19 & 13 & 171 & $0.40 \pm 3.89$ & 0.41 & 6.22 \\
\hline Pot & $126(15)$ & 763 & 7.32 & 8 & 110 & $0.87 \pm 4.17$ & 0.25 & 4.00 \\
\hline AFC & $88(14)$ & 763 & 7.32 & 5 & 110 & $1.18 \pm 5.53$ & 0.16 & 4.00 \\
\hline "Other" & $235(16)$ & 338 & 3.24 & 7 & 73 & $0.31 \pm 2.42$ & 0.22 & 2.65 \\
\hline Jerrycan & $1717(25)$ & 273 & 2.62 & 9 & 36 & $0.02 \pm 0.35$ & 0.29 & 1.31 \\
\hline Well & 0 & 0 & 0 & 0 & 0 & 0 & 0 & 0 \\
\hline Treehole & 0 & 0 & 0 & 0 & 0 & 0 & 0 & 0 \\
\hline Total & 6566 (330) & 10,420 & 100 & 133 & 2750 & & & 100 \\
\hline
\end{tabular}

Abbreviations: AFC animal feeding containers, SDC small domestic containers, +ve positive

types during the three seasons, i.e. long rainy (April-June), short dry (July-September), and short rainy (OctoberDecember), than in the long dry (January-March) season in both regions (Fig. 4). In the coast region, during the long rainy season except for tree holes, wells and others, nearly all container types were important producers of $A e$. aegypti immatures. In contrast, in the western region pots were the main producers of Ae. aegypti immatures in all seasons (Fig. 4b). Productivity among seasons varied significantly (Kruskal-Wallis test, $\chi^{2}=83.2, d f=3$, $P<0.0001$ ) with more immatures in long rainy seasons and the least in long dry seasons.

\section{Oviposition activity}

A total of 59,641 eggs were collected from 3538 ovitraps during the 24-month period in western (Chulaimbo and
Kisumu) and coastal regions (Msambweni and Ukunda). Of these, $97.1 \%$ were of Ae. aegypti, 2.3\% Ae. simpsoni and $0.5 \%$ Culex spp. Significantly more ovitraps were positive for Ae. aegypti eggs outdoors than indoors $\left(\chi^{2}=584.3\right.$, $d f=1, P<0.0001)$ and contained more eggs both in the western region [436 (46. 8\%) containing 24,949 eggs vs 37 (4.0\%) containing 920 eggs] and the coastal region [418 (50.0\%) containing 26,618 eggs vs 160 (19.1\%) containing 7154 eggs]. Mean number of eggs per trap (Mean egg index) was significantly higher (Kruskal-Wallis test, $\chi^{2}=$ 91.2, $d f=3, P<0.0001$ ) in the three seasons, i.e. long rainy (April-June), short dry (July-September) and short rainy (October-December) than in the dry season (JanuaryMarch) for both regions. However, the percentage of positive ovitraps (Ovitrap positivity index) and mean egg index were notably higher $(P<0.0001)$ in the coastal region.

Table 5 Relative importance of container categories in the western region, Kenya

\begin{tabular}{lllllllll}
\hline $\begin{array}{l}\text { Container } \\
\text { category }\end{array}$ & $\begin{array}{l}\text { No. of } \\
\text { container } \\
\text { visits (+ve) }\end{array}$ & $\begin{array}{l}\text { Total no. of larvae } \\
\text { in each container } \\
\text { category }\end{array}$ & $\begin{array}{l}\text { Proportion of larvae } \\
\text { in each container } \\
\text { category (\%) }\end{array}$ & $\begin{array}{l}\text { No. of } \\
\text { containers } \\
\text { with pupae }\end{array}$ & $\begin{array}{l}\text { Total } \\
\text { no. of } \\
\text { pupae }\end{array}$ & $\begin{array}{l}\text { No. of pupae per } \\
\text { container type } \\
\text { (Mean } \pm \text { SD) }\end{array}$ & $\begin{array}{l}\text { Frequency of } \\
\text { containers with } \\
\text { pupae (\%) }\end{array}$ & $\begin{array}{l}\text { Proportion of pupa } \\
\text { in each container } \\
\text { category (\%) }\end{array}$ \\
\hline Pot & $1915(417)$ & 1776 & 49.58 & 55 & 340 & $0.18 \pm 1.22$ & 2.87 & 45.39 \\
Tire & $276(125)$ & 647 & 18.06 & 41 & 185 & $0.67 \pm 1.81$ & 14.86 & 24.70 \\
SDC & $1652(108)$ & 435 & 12.14 & 12 & 61 & $0.04 \pm 0.52$ & 0.73 & 8.14 \\
Drum & $801(56)$ & 293 & 8.18 & 14 & 53 & $0.66 \pm 0.66$ & 1.75 & 7.08 \\
AFC & $145(16)$ & 71 & 1.98 & 6 & 27 & $0.19 \pm 0.94$ & 4.14 & 3.60 \\
Bucket & $3409(9)$ & 48 & 1.34 & 3 & 13 & $0.003 \pm 0.15$ & 0.09 & 1.74 \\
Jerrycan & $4588(20)$ & 35 & 0.98 & 3 & 6 & $0.001 \pm 0.06$ & 0.07 & 0.80 \\
Well & $61(5)$ & 48 & 1.34 & 2 & 5 & $0.08 \pm 0.46$ & 3.28 & 0.67 \\
Other & $2695(7)$ & 41 & 1.14 & 1 & 2 & $0.0001 \pm 0.04$ & 0.04 & 0.27 \\
Treehole & $36(21)$ & 188 & 5.25 & 13 & 57 & $1.58 \pm 2.48$ & 36.11 & 7.61 \\
Total & 15,578 & 3582 & 100.00 & 150 & 749 & & & 100
\end{tabular}



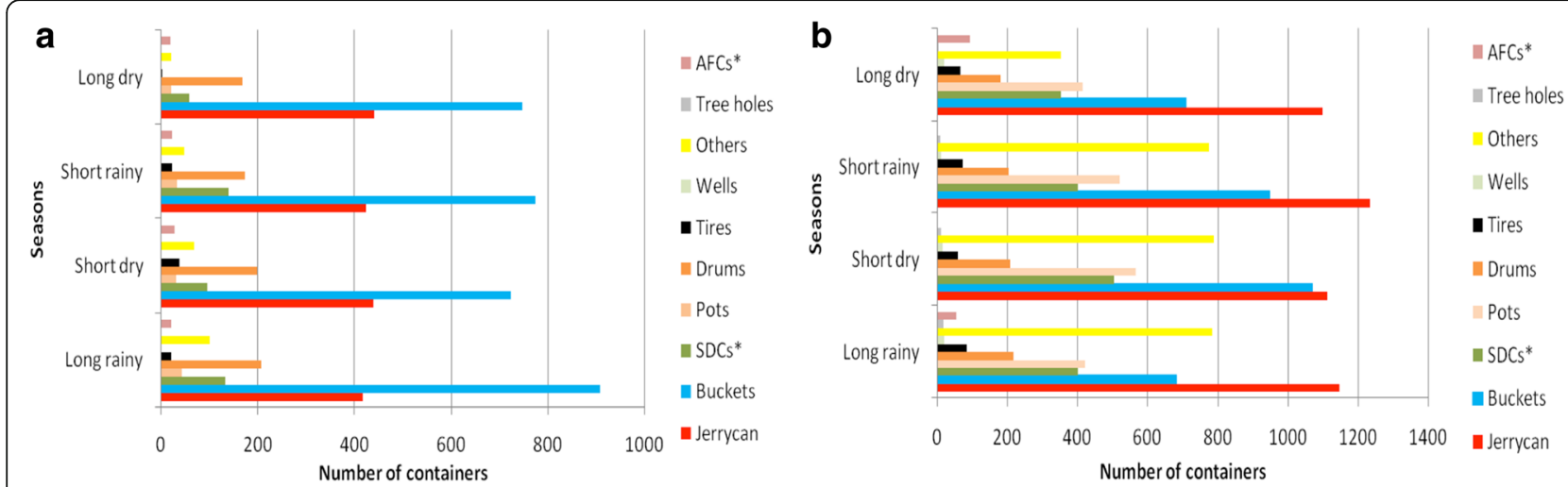

Fig. 3 Seasonal abundance of Ae. aegypti larval habitats in a coastal [Msambweni (rural) and Ukunda (urban)] and b western [Chulaimbo (rural) and Kisumu (urban)] regions, between May 2014 and February 2016. Seasons: long rainy (April-June), short dry (July-September), short rainy (October-December); long dry (January-March). Abbreviations: AFC, animal feeding troughs; SDC, small domestic containers

\section{Discussion}

In this study, we report a notable preference for outdoor breeding by Ae. aegypti, contrary to earlier findings from the region [13], but consistent with other recent findings elsewhere [20, 25, 41-43]. This is clearly indicated by significantly more Ae. aegypti immatures found in containers located outdoors, despite a higher number of containers with water indoors (Tables 1,2). Further in support of this finding, oviposition surveys in all the study sites show significantly higher oviposition activity by Ae. aegypti outdoors than indoors. Drums, buckets, discarded tires, and small domestic containers are the key containers for Ae. aegypti development in all study sites, consistent with other studies [2, 19, 22, 44, 45]. In addition, water storage containers produced most of the immatures recorded, underscoring the importance of such category of containers in these regions. Significantly higher Ae. aegypti breeding activity was observed in the coastal region than in the west, even though the west had a notably higher number of potential breeding habitats. Container habitats of Ae. aegypti are consistently available throughout the year in all the study sites; however, Ae. aegypti was found to breed in more container types during the wet and short dry seasons.

The observed increased outdoor breeding activity by Ae. aegypti suggests an adaptation to outdoor and peridomestic habitats [20], a trend that is most likely to have epidemiologically important implications for vector control practices and prevention of virus transmission. This calls for more emphasis to be placed on the outdoor larval habitats in targeted source reduction measures in the study areas. Widespread use of insecticide impregnated bed nets in our study sites $[33,46,47]$ could be a factor accounting for the preference of outdoor breeding by Ae. aegypti. Traditionally Ae. aegypti has been demonstrated to be a domestic species that is strongly endophilic occurring in bedrooms, kitchens, bathrooms and living rooms, where it rests on walls, hanging cloths, bednets
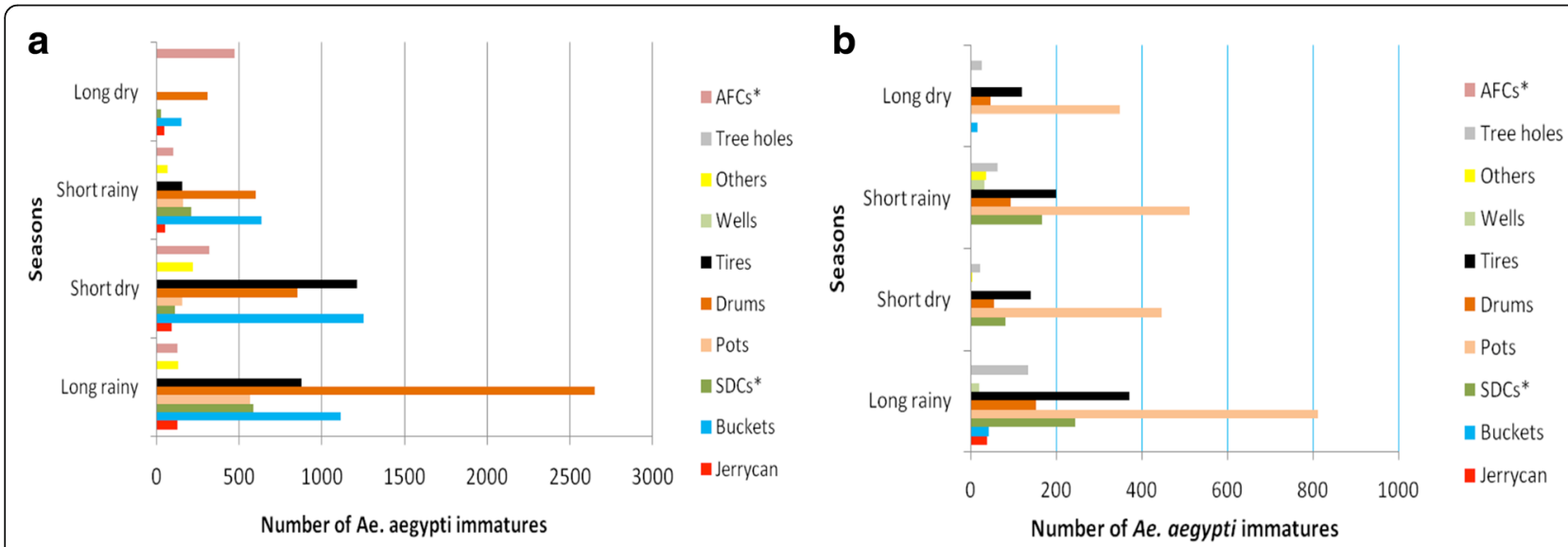

Fig. 4 Seasonal abundance of Ae. aegypti immatures in different container types in a the coastal (Msambweni and Ukunda) and $\mathbf{b}$ western (Chulaimbo and Kisumu) regions, between May 2014 to Feb 2016. Seasons: long rainy (April-June), short dry (July-September), short rainy (October-December); long dry (January-March). Abbreviations: AFC, animal feeding troughs; SDC, small domestic containers 
and under furniture [48-50]. This may bring resting females into contact with insecticide-treated materials that are likely to kill or at least repel them from indoor resting sites. In our ongoing study (unpublished data), Aedes mosquitoes have been found to be susceptible to insecticides that are commonly used in bednets. However, further studies are required to confirm and possibly establish factors that can lead to this observed trend toward outdoor and peridomestic habitats.

Low indoor productivity in our study sites can also be attributed to human activities related to the use of domestic water receptacles. Most indoor containers are commonly used for hygiene, cooking and drinking and are subject to frequent emptying and cleaning which can effectively interrupt mosquito development. They are therefore much less likely to harbor Ae. aegypti immatures [22, 25]. Moreover, most of the indoor containers for water storage were often covered; this could have possibly contributed to many of them being unproductive. Containers with covers have been found to have a lower probability of infestation by $\mathrm{Ae}$ des mosquitoes [22] by preventing gravid females from accessing oviposition sites [45, 51].

Tires provided good breeding sites for Aedes mosquitoes and are responsible for producing $>30 \%$ of immatures collected from all larval habitats in outdoor locations of urban areas. The importance of tires as breeding sites of Ae. aegypti has been highlighted before $[18,19,51-53]$, and recycling as a means to manage used tires in dengue control has gained popularity around the globe [30]. In the urban areas of our study sites, recycling of tires is limited to small-scale use for making sandals and soles of shoes. Therefore, intensifying other recycling options [30] is highly recommended. In addition, storage of tires in a dry environment and proper disposal of used tires should be encouraged in instances where recycling may not be feasible.

Buckets and jerrycans were found in large numbers in all the study sites, but their importance as breeding sites for Ae. aegypti mosquitoes was limited to the coastal region, especially outdoors. Unlike buckets, many jerrycans were consistently present indoors in the study sites, but they were not equally productive. Some studies have identified jerrycans as among the preferred outdoor breeding habitats $[18,19]$, contrary to the situation in our study sites. Low productivity by this container type can possibly be attributed to their popular usage in short-term storage of water and therefore being subject to frequent emptying and cleaning, which effectively interrupt the breeding cycle of Ae. aegypti immatures [30, 54]. Water-holding containers that are in frequent use within the domestic environment were observed to be less likely to harbor Aedes immatures [22], and this can make water storage possible without necessarily creating breeding sites for Aedes mosquitoes.
Animal feeding containers were only found in the coastal region, and their importance was particularly noticed in urban site where concrete troughs and cut tires, popular as watering points for cattle and goats in backyards of some homesteads, provided good larval sites for Ae. aegypti mosquitoes. The importance of water storage containers is due to the fact that they can hold sufficiently large volumes of water for considerably longer periods that are adequate for complete larval development. However, breeding in these containers can be eliminated by provision of tight fitting covers and mesh screens to prevent access by gravid mosquitoes $[30,45,51]$.

In this study, removal or proper management of key containers could result in over a $65 \%$ reduction in $A e$. aegypti immature population. This would translate into a corresponding reduction in Ae. aegypti population in the study areas, since pupae can be used as proxy estimates of adult Ae. aegypti mosquitoes [2].

Higher Ae. aegypti breeding activity at our coastal study sites can be attributed to many factors. Our coastal urban site is characterized by unplanned settlements and a large population of low income earners in the informal business sector, where poor hygiene coupled with inadequate water, sewer and waste management systems are common. These conditions have been found to contribute significantly to the proliferation of breeding sites for Ae. aegypti $[55,56]$. In addition the practice of keeping domestic animals in backyards of these neighborhoods, probably to boost the low income levels, provides more breeding opportunities for the highly adaptive $A e$. aegypti mosquito [57] which readily exploits the water receptacles meant for animal drinking and feeding. The comparatively higher breeding activity by Ae. aegypti observed in the coastal sites could possibly account for the dengue outbreaks reported mostly in the coastal region as observed in the recent past [9].

The year-round activity of Ae. aegypti can be associated with the lack of a reliable water supply system, and reliance on borehole water, well and rain water collection, necessitating water storage in households. During the long dry season, in particular, drums, buckets and pots become important producers of Ae. aegypti immatures in both regions. Ae. aegypti breeding in our study sites is closely related to the rainfall patterns in the two regions, with higher production of immatures during the rainy season, when environmental conditions are also optimal for adult activity, which translates into higher productivity of containers.

Of the high number of water-holding containers inspected, only a few were productive for Ae. aegypti, and most of them were located outdoors. Identification of key larval habitats for Ae. aegypti as part of vector control programs $[45,58]$ will help target larval source 
reduction measures. Dengue is primarily a problem of human activities that create breeding opportunities for potential vectors, the control of which can be achieved by physical means $[30,50]$. In our study, good management practices for water storage containers $[22,50]$, recycling and proper disposal of discarded tires and small domestic containers [30] are recommended in order to achieve a significant reduction in Aedes population outdoors, especially during the rainy season when the latter type of containers become important breeding habitats. In addition, provision of reliable piped water supply to households in the study sites throughout the year would reduce storage of water in containers and thus control Ae. aegypti development sites.

The results of this study should be interpreted with caution since we systematically and repeatedly sampled households that were randomly selected for larval and ovitrap surveys. Though this sampling design enabled us to conduct the surveys over an extended period, we note that the study population may change its behavior over time, which in turn, may impact our findings. In addition, although our sample size of 20 sentinel houses in each of the four study sites may have been statistically inadequate, we were not able to inspect other larval sites beyond the large number in the individual sentinel households, given limited resources and larval surveys being labor intensive.

We distinguished Ae. aegypti subspecies morphologically following keys as provided by Edwards [37], Mattingly [38] and Huang [39]. While morphological identification of the subspecies is not optimal, the more sensitive molecular techniques are yet to be fully developed [59], and are not readily available in field conditions. Ae. aegypti aegypti has been reported to be predominantly domestic and peridomestic, while Ae. aegypti formosus mostly sylvatic [57, 59-61] . We identified all the Ae. aegypti in this study as Ae. aegypti aegypti. Given that all our samples are from the domestic or the immediate peridomestic environment, (within a range $10 \mathrm{~m}$ around sampling houses), we are confident that the presence of Ae. aegypti formosus did not have a significant impact on our findings.

\section{Conclusions}

The results of this study indicate that Ae. aegypti breeding habitats are abundant outdoors and are diverse both in the coastal and western regions of Kenya. However, a limited number of container types are responsible for the majority of the adult vector production. Targeting source reduction efforts toward these productive container types may be a cost-effective way to reduce the abundance of the dengue vector and arboviral transmission in these regions.

\section{Abbreviations}

CDC: Centers for Disease Control; DENV: Dengue virus; KEMRI: Kenya Medical Research Institute; PAHO: Pan American Health Organization; VBDCU: Vector borne disease control unit; WHO: World Health Organization

\section{Acknowledgments}

We thank the residents at our two study sites for their support during the study. Our sincere gratitude goes to Joyce Bandika, Juma Hamadi and Henry Maleka for technical help during mosquito surveys, Rashid Motwa, Riziki Kirenje, Maulidi Wazumo, Hamisi Masemo, Saumu Kushinda and Riziki Jaso who assisted in field survey. We greatly appreciate the Vector Borne Disease Control Unit (VBDCU) at the Msambweni county referral hospital and the Kenya Medical Research Institute (KEMRI), Kisian, Kisumu for laboratory and insectary space. We also thank Richard Ndivo of KEMRI-CDC, Kisumu for technical help during statistical analyses.

\section{Funding}

This study was funded by a program award RO1 Al102918 from the National Institutes of Health, USA.

\section{Availability of data and materials}

The datasets supporting the conclusions of this article are included within the article. Raw data are available from the corresponding author on request.

\section{Authors' contributions}

HNN, FMM, BAN, UK and ADL conceived and designed the study. HNN, PSM, JM, PA collected data. HNN and FMM analyzed the data. HNN, FMM, BAN,

LWI, DM, JV, UK and ADL wrote the manuscript. All authors read and approved the final manuscript.

\section{Ethics approval and consent to participate}

This study was approved by ethical review committee of the Kenya Medical Research Institute (KEMRI) (Protocol no. KEMRI 2611). Study objectives and procedures were explained to the local health authorities, community leaders and residents of the study area. Oral consent to permit mosquito surveys in houses was obtained from household heads in accordance to the ethical standards of the Kenya Medical research institutes' ethical review committee.

\section{Consent for publication}

Not applicable.

\section{Competing interests}

The authors declare that they have no competing interests.

\section{Author details}

${ }^{1}$ Department of Biological Sciences, Chuka University, Chuka, Kenya. ${ }^{2}$ Department of Environment and Health Sciences, Technical University of Mombasa, Mombasa, Kenya. ${ }^{3}$ Centre for Global Health Research, Kenya Medical Research Institute, Kisumu, Kenya. ${ }^{4}$ Vector Borne Disease Unit, Msambweni, Kenya. ${ }^{5}$ Department of Zoology, School of Biological Sciences University of Nairobi, Nairobi, Kenya. ${ }^{6}$ Vector Borne Disease Unit, Center for Global Health and Diseases, Nairobi, Kenya. ${ }^{7}$ Department of Environmental Sciences, Emory University, Atlanta, GA, USA. ${ }^{8}$ Department of Pediatrics, Division of Infectious Diseases, Stanford University School of Medicine, Stanford, California, USA.

Received: 17 March 2017 Accepted: 4 July 2017

Published online: 12 July 2017

\section{References}

1. Troyo A, Calderon-Arguedas O, Fuller D, Solano M, Avendafio A, Arheart K, et al. Seasonal profiles of Aedes aegypti (Diptera: Culicidae) larval habitats in an urban area of Costa Rica with a history of mosquito control. J Vector Ecol. 2008:33:76-88.

2. Focks DA, Chadee DD. Pupal survey: an epidemiologically significant surveillance method for Aedes aegypti: an example using data from Trinidad. Am J Trop Med Hyg. 1997;56:159-67.

3. Service MW. Importance of ecology in Aedes aegypti control. Southeast Asian J Trop Med Public Health. 1992;23:681-8. 
4. Dom NC, Ahmad AH, Ishak AR, Ismail R. Assessing the risk of dengue fever based on the epidemiological, environmental and entomological variables. Procedia Soc Behav Sci. 2013;105:183-94.

5. Armistead JS, Nishimura N, Arias JR, Lounibos LP. Community ecology of container mosquitoes (Diptera: Culicidae) in Virginia following invasion by Aedes japonicus. J Med Entomol. 2012;49:1318-27.

6. Johnson BK, Ochieng D, Gichogo A, Okiro M, Libondo D, Kinyanjui P. Epidemic dengue fever caused by dengue type 2 virus in Kenya: preliminary results of human virological and serological studies. East Afr Med J. 1982;59:781-4.

7. Ellis E, Neatherlin J, Delorey M, Ochieng M, Mohamed A, Mogeni D, et al. A household serosurvey to estimate the magnitude of a dengue outbreak in Mombasa, Kenya, 2013. PLoS Negl Trop Dis. 2015;9:e0003733.

8. Akhwale W. Dengue fever outbreak response. Nairobi: Department of Disease Prevention and Control. MOH. 2013;7:1-2.

9. Ochieng C, Ahenda P, Vittor AY, Nyoka R, Gikunju S, Wachira C, et al. Seropreverlence of infections with dengue, rift valley fever and chikungunya viruses in Kenya. PLoS Negl Trop Dis. 2015;10:e0132645.

10. Blaylock JM, Maranich A, Bauer K, Nyakoe N, Waitumbi J, Martinez LJ, et al. The seroprevalence and seroincidence of dengue virus infection in western Kenya. Travel Med Infect Dis. 2011;9:246-8.

11. Sutherland LJ, Cash AA, Sang RC, Huang Y, Malhotra I, King CL, et al. Serological evidence of arboviral infections among humans in Kenya. Am J Trop Med Hyg. 2011;85:158-61.

12. Morrill J, Johnson B, Hyams C, Okoth F, Tukei P, Mugambi M, et al. Serological evidence of arboviral infections among humans of coastal Kenya. J Trop Med Hyg. 1991;94:166-8.

13. Trpis M, Hausermann W. Dispersal and other population parameters of Aedes aegypti in African village and their possible significance in epidemiology of vector-borne diseases. Am J Trop Med Hyg. 1986;35:1263-79.

14. Yalwala S, Clark J, Oullo D, Ngonga D, Abuom D, Wanja E, et al. Comparative efficacy of existing surveillance tools for Aedes aegypti in western Kenya. J Vector Ecol. 2015;4:301-7.

15. Carolyn S, Felix B, Aman B, Sarabeth A, Joel L, Rosemary S, et al. Evolution of mosquito preference for humans linked to an odorant receptor. Nature. 2014;515:222-7.

16. Zahouli J, Utzinger J, Adja M, Müller P, Malone D, Tano Y, et al. Oviposition ecology and species composition of Aedes spp. and Aedes aegypti dynamics in variously urbanized settings in arbovirus foci in southeastern Côte d'Ivoire. Parasit Vectors. 2016;9:523.

17. Piovezan R, Rosa L, Rocha M, de Azevedo T, Von Tuben C. Entomological surveillance, spatial, and diversity of Culicidae (Diptera) immatures in rural area of the Atlantic forest biome, state of São Paulo, Brazil. J Vector Ecol. 2013;38:317-25.

18. Getachew D, Tekie H, Gebre-Michael T, Balkew M, Mesfin A. Breeding sites of Aedes aegypti: potential dengue vectors in Dire Dawa, east Ethiopia. Interdiscip Perspect Infect Dis. 2015;ID706276:1-8.

19. Midega JT, Nzovu J, Kahindi S, Sang RC, Mbogo C. Application of the pupal/ demographic-survey methodology to identify the key container habitats of Aedes aegypti (L.) in Malindi district, Kenya. Ann Trop Med Parasitol. 2006;100:S61-72.

20. Saifur RGM, Dieng $H$, Hassan AA, Salmah MRC, Satho T, Miake F, et al. Changing domesticity of Aedes aegypti in northern peninsular Malaysia: reproductive consequences and potential epidemiological implications. PLoS One. 2012;7:e30919.

21. Wongkoon $S$, Jaroensutasinee $M$, Jaroensutasinee $K$, Preechaporn $W$. Development sites of Aedes aegypti and Ae. albopictus in Nakhon Si Thammarat, Thailand. Dengue Bull. 2007;31:141-52.

22. Hiscox A, Kaye A, Vongphayloth K, Banks I, Piffer M, Khammanithong P, et al. Risk factors for the presence of Aedes aegypti and Aedes albopictus in domestic water-holding containers in areas impacted by the Nam Theun 2 hydroelectric project, Laos. Am J Trop Med Hyg. 2013;88:1070-8.

23. Brown J, McBride C, Johnson P, Ritchie S, Paupy C, Bossin H, et al. Worldwide patterns of genetic differentiation imply multiple 'domestications' of Aedes aegypti, a major vector of human diseases. Proc Biol Sci. 2011;278:2446-54.

24. Subra R. The regulation of preimaginal populations of Aedes aegypti $\mathrm{L}$. (Diptera: Culicidae) on the Kenya coast. I. Preimaginal population dynamics and the role of human behaviour. Ann Trop Med Parasitol. 1983;77:195-201.

25. Maciel-de-Freitas R, Marques W, Peres R, Cunha P, Lourenço O. Variation in Aedes aegypti (Diptera: Culicidae) container productivity in a slum and a suburban district of Rio de Janeiro during dry and wet seasons. Mem Inst Oswaldo Cruz. 2007;102:489-6.
26. Strickman D, Kittayapong P. Laboratory demonstration of oviposition by Aedes aegypti (Diptera: Culicidae) in covered water jars. J Med Entomol. 1993;30:947-9.

27. Chikungunya- Kenya. Emergencies Preparedness and Response. Disease outbreak news. [http://who.int/csr/don/09-august-2016-chikungunya-kenya/ en/]. Accessed 8 Mar 2017

28. Sergon K, Njuguna C, Kalani R, Ofula V, Onyango C, Konongoi L, et al. Seroprevalence of chikungunya virus (CHIKV) infection on Lamu island, Kenya, October 2004. Am J Trop Med Hyg. 2008;78:333-7.

29. LaBeaud AD, Banda T, Brichard J, Muchiri EM, Mungai PL, Mutuku FM, et al. High rates of o'nyong nyong and chikungunya virus transmission in coastal Kenya. PLoS Negl Trop Dis. 2015;9:e0003436.

30. WHO. Dengue: guidelines for diagnosis, treatment, prevention and control New edition. WHO/HTM/NTD/DEN/2009.1. 2009.

31. Chadee DD. Dengue cases and Aedes aegypti indices in Trinidad. West Indies Acta Trop. 2009;112:174-80.

32. Achee N, Gould F, Perkins T, Reiner R, Morrison A, Ritchie S, et al. A critical assessment of vector control for dengue prevention. PLoS Negl Trop Dis. 2015:9:e0003436.

33. Mutuku F, King C, Mungai $P$, Charles Mbogo C, Mwangangi J, Muchiri E, et al. Impact of insecticide-treated bed nets on malaria transmission indices on the south coast of Kenya. Malar J. 2011;10:536.

34. Onyango S, Kitron U, Mungai P, Muchiri E, Kokwaro E, King C, et al. Monitoring malaria vector control interventions: effectiveness of five different adult mosquito sampling methods. J Med Entomol. 2013;50:1140-51.

35. Minakawa N, Dida G, Sonye G, Futami K, Njenga S. Malaria vectors in Lake Victoria and adjacent habitats in western Kenya. PLoS One. 2011;7:e32725.

36. Chadee D, Doon R, Severson D. Surveillance of dengue fever cases using a novel Aedes aegypti population sampling method in Trinidad, West Indies: the cardinal points approach. Acta Trop. 2007;104:1-7.

37. Edwards F. Mosquitoes of the Ethiopian region III: Culicine adults and pupae. London: The Trustees of the British Museum; 1941.

38. Mattingly P. Genetical aspects of the Aedes aegypti problem. I: taxonomy and bionomics. Ann Trop Med Parasitol. 1958;51:392-408.

39. Huang Y. The subgenus Stegomyia of Aedes in the Afrotropical region with keys to the species (Diptera: Culicidae). Zootaxa. 2004;700:1-120.

40. Chadee DD. Oviposition strategies adopted by gravid Aedes aegypti (L.) (Diptera: Culicidae) as detected by ovitraps in Trinidad, West Indies (2002-2006). Acta Trop. 2009;111:279-83.

41. Garcia-Rejon J, Loroño-Pino M, Farfan-Ale J, Flores-Flores L, Rosado-Paredes E, Rivero-Cardenas N, et al. Dengue virus-infected Aedes aegypti in the home environment. Am J Trop Med Hyg. 2008;79:940-50.

42. Morrison A, Gray K, Getis A, Astete H, Sihuincha M, Focks D, et al. Temporal and geographic patterns of Aedes aegypti (Diptera: Culicidae) production in lquitos, Peru. J Med Entomol. 2004;41:1123-42.

43. Dhimal M, Gautam I, Joshi H, O'Hara R, Ahrens B, Kuch U. Risk factors for the presence of chikungunya and dengue vectors (Aedes aegypti and Aedes albopictus), their altitudinal distribution and climatic determinants of their abundance in central Nepal. PLoS Negl Trop Dis. 2015:9:e0003545.

44. Lenhart AE, Castillo CE, Oviedo M, Villegas E. Use of the pupal/ demographic-survey technique to identify the epidemiologically important types of containers producing Aedes aegypti (L.) in a dengue-endemic area of Venezuela. Ann Trop Med Parasitol. 2006:100:\$53-9.

45. Chadee DD, Huntley S, Focks DA, Chen AA. Aedes aegypti In Jamaica, West Indies: container productivity profiles to inform control strategies. Tropical Med Int Health. 2009;14:220-7.

46. National Malaria Control Programme (NMCP), Kenya National Bureau of Statistics (KNBS), ICF International. Kenya Malaria Indicator Survey, 2015. Nairobi and Rockville: NMCP, KNBS, and ICF International; 2016.

47. Bayoh M, Walker E, Kosgei J, Ombok M, Olang G, Killeen G, et al. Persistently high estimates of late night, indoor exposure to malaria vectors despite high coverage of insecticide treated nets. Parasit Vectors. 2014;7:380.

48. Chadee DD. Resting behaviour of Aedes aegypti in Trinidad: with evidence for the re-introduction of indoor residual spraying (IRS) for dengue control. Parasit Vectors. 2013;6:255

49. Perich M, Davila G, Turner A, Garcia A, Nelson M. Behavior of resting Aedes aegypti (Diptera: Culicidae) and its relation to ultra-low volume adulticide efficacy in Panama City, Panama. J Med Entomol. 2000;37:541-6.

50. PAHO. Dengue and dengue haemorrhagic fever in the Americas: guidelines for prevention and control. Washington D.C: Pan American Health Organization; 1994. 
51. Philbert A, ljumba J. Preferred breeding habitats of Aedes aegypti (Diptera: Culicidae) mosquito and its public health implications in Dar es salaam. Tanzania J Environ Res Manage. 2013;4:0344-51.

52. Trpis M. Seasonal changes in the larval populations of Aedes aegypti in two biotopes in Dar es Salaam. Tanzania Bull World Health Organ. 1972;47:245-55.

53. Chambers D, Young L, Hills H. Backyard mosquito larval habitat availability and use as influenced by census tract determined resident income levels. J Am Mosq Control Assoc. 1986;2:539-44.

54. Christophers S. Aedes aegypti (L) the yellow fever mosquito: its life history, bionomics and structure. 1st ed. Cambridge: Cambridge University Press; 1960.

55. Gubler D. Denque and denque hemorrhagic fever. Clin Microbiol Rev. 1998;11:480-96.

56. Gubler D. Epidemic dengue/dengue hemorrhagic fever as a public health, social and economic problem in the 21 st century. Trends Microbiol. 2002:10:100-2.

57. Powel J, Tabachnick W. History of domestication and spread of Aedes aegypti - a review. Mem Inst Oswaldo Cruz. 2013:108:11-7.

58. Marylene BA. Assessment of Aedes aegypti pupal productivity during the dengue vector control program in a costal urban centre of São Paulo state. Brazil J Insects. 2014;2014:1-9.

59. McBride C, Baier F, Omondi A, Spitzer S, Lutomiah J, Sang R, et al. Evolution of mosquito preference for humans linked to an odorant receptor. Nature. 2014:515:222-7.

60. Trpis M, Hausermann W. Demonstration of differential domesticity of Aedes aegypti (L.) (Diptera: Culicidae) in Africa by mark-release-recapture. Bull Ent Res. 1975;65:199-208.

61. Lounibos L. Genetic control trials and the ecology of Aedes aegypti at the Kenyan coast. In: Takken W, Scott WT, editors. Ecological aspects for application of genetically modified mosquitoes. Dordrecht: Kluwer Academic Publishers; 2003. p. 33-4

\section{Submit your next manuscript to BioMed Central and we will help you at every step:}

- We accept pre-submission inquiries

- Our selector tool helps you to find the most relevant journal

- We provide round the clock customer support

- Convenient online submission

- Thorough peer review

- Inclusion in PubMed and all major indexing services

- Maximum visibility for your research

Submit your manuscript at www.biomedcentral.com/submit

) Biomed Central 